\title{
ZASTOSOWANIE DYNAMICZNYCH MODELI PANELOWYCH W ANALIZIE DETERMINANT PRZESTĘPCZOŚCI W POLSCE W LATACH 2005-2016
}

\author{
Łukasz Gadomski \\ Wydział Ekonomiczno-Socjologiczny, Uniwersytet Łódzki \\ Maciej Malaczewski \\ Wydział Ekonomiczno-Socjologiczny, Uniwersytet Łódzki \\ ORCID: https://orcid.org/0000-0001-7798-2581
}

\begin{abstract}
Streszczenie
Celem niniejszego badania jest weryfikacja wpływu czynników zarówno ekonomicznych, jak i społecznych, mających wpływ na kształtowanie się przestępczości w Polsce. Dane wykorzystane w badaniu charakteryzują się częstotliwością roczną i prezentowane są w ramach przekroju wojewódzkiego. Przedział czasowy analizy obejmuje lata 2005-2016 z uwagi na ograniczenie dostępności danych. W ramach przeprowadzonych analiz dokonano weryfikacji istotności zmiennych: współczynnik feminizacji, inflacja, współczynniki urbanizacji oraz gęstości zaludnienia. Dodatkowo zdecydowano o uwzględnieniu w badaniu wskaźnika syntetycznego reprezentującego poziom jakości życia w regionie. Weryfikacja istotności wybranych zmiennych została przeprowadzona poprzez budowę modelu ekonometrycznego. $Z$ uwagi na wykorzystanie danych panelowych oraz przekonanie autorów o występowaniu związku pomiędzy przeszłymi wartościami przestępczości a ich obecnymi realizacjami, zdecydowano się na wykorzystanie dynamicznych modeli panelowych (metoda FDGMM).
\end{abstract}

Słowa kluczowe: determinanty przestępczości, model przestępczości, dynamiczne modele panelowe.

JEL Class: C23, K14, 010. 


\section{WSTĘP}

Przestępczość jest zjawiskiem złożonym, w znacznym stopniu wpływającym na powszechnie występujący ład społeczny. Wysoki poziom przestępczości skutkuje brakiem poczucia bezpieczeństwa, którego niespełnienie, zgodnie z teorią potrzeb Maslowa, nie pozwala jednostce na dążenie do własnego rozwoju. Nie jest więc zaskoczeniem, że od wielu już lat podejmowane są działania mające na celu eliminację tego wysoce niepożądanego zjawiska społecznego. Jest to jednak proces niezwykle trudny z uwagi na jego wieloaspektowość i ciągle zachodzące w nim zmiany, na przykład rozwój technologiczny ułatwił dokonywanie przestępstw, ale także rozszerzył zakres czynów karalnych o nowe, wcześniej nie występujące kategorie. Z uwagi na wskazany ciągły proces dostosowawczy podejmowanych działań, redukcja zjawiska przestępczości staje się niezwykle kosztowna.

Literatura przedmiotu sugeruje wiele czynników mogących potencjalnie wpłynąć na jednostkę dokonującą czynu zabronionego. Należą do nich między innymi: czynniki psychologiczne, czynniki ekonomiczne, czynniki społeczne czy czynniki kulturowe. W niniejszej pracy celem jest weryfikacja wpływu wybranych czynników determinujących zjawisko przestępczości, w szczególności zbadanie występowania istotnego wpływu jakości życia na działalność przestępczą.

Struktura pracy jest następująca. W części pierwszej dokonano przeglądu literatury tematu ukierunkowanego na badania związane z czynnikami wpływającymi na poziom przestępczości. W części drugiej omówiono specyfikę zjawiska przestępczości w Polsce. W części trzeciej zaprezentowano sposób konstrukcji wskaźnika jakości życia, który wykorzystano w badaniach w niniejszej pracy. W części czwartej zaprezentowano wyniki badań ekonometrycznych związanych z tym zjawiskiem. Całość kończy podsumowanie.

\section{CZYNNIKI WPŁYWAJĄCE NA PRZESTĘPCZOŚĆ}

Ważne jest, aby każdorazowo w przypadku analizy zjawiska przestępczości uwzględnić występujące na badanym obszarze normy prawne (definicja przestępstwa, rodzaje przestępstw), normy kulturowe (zwłaszcza dotyczące dominujących wyznań religijnych) oraz zachodzące na przestrzeni czasu w nich zmiany. Bardzo często powodują one brak porównywalności lub spadek jakości zebranych danych statystycznych, zwłaszcza w przypadku ich analizy w ramach dużych obszarów geograficznych (np. państwa). W przypadku norm prawnych, może to odnosić się do zmiany zakresu czynu prawnego. Aspekt norm kulturowych jest bardziej złożony i podlega częstszym zmianom, wiąże się z czynami uznawanymi przez społeczeństwo za sprzeczne z ich wartościami i dotyczy między innymi różnic w postrzeganiu uboju rytualnego, konsumpcji środków odurzających czy też granic 
stosowania przemocy. Nie jest więc zaskoczeniem fakt, że nie występuje w literaturze kompletny zestaw czynników uznawanych za determinanty przestępczości. Najbardziej znane z nich odnoszą się jednak do sfery ekonomicznej i demograficznej społeczeństwa.

W badaniach naukowych bardzo często jako istotny czynnik wpływający na przestępczość uznaje się wskaźnik urbanizacji lub gęstość zaludnienia [Kądziołka 2014: 15-17]. Wynika to między innymi z charakteru dokonywania niektórych przestępstw, jak np. kradzieży, gdzie przestrzeń publiczna w znaczący sposób ułatwia dokonanie czynu zabronionego. Większe nagromadzenie ludzi wpływa także na wzrost poczucia anonimowości, obywatele popełniają wówczas przestępstwa z uwagi na to, że uznają się za trudno wykrywalnych dla organów ścigania [Czarnecki 2011: 9-11].

Za kolejny z nich uznaje się stopę bezrobocia. Potwierdzenie słuszności wpływu tego czynnika na przestępczość znajdziemy w teorii zaproponowanej przez G. Beckera, która zakłada, że podczas podejmowania decyzji dotyczącej podjęcia przestępstwa lub jego zaprzestania, człowiek kieruje się kalkulacją zysków i strat z niej wynikających. Decyzja o popełnieniu przestępstw zostanie podjęta wyłącznie, gdy oczekiwane $\mathrm{z}$ niej korzyści są wyższe niż przewidywane koszty [Becker 1968: 169-217]. W tej sytuacji zakłada się, że osoba bezrobotna charakteryzuje się obniżonym kosztem działań przestępczych, ponieważ koszt utraconych możliwości jest dla niej zdecydowanie mniejszy. W dotychczasowych badaniach udowodniono również, że koszt utraconych możliwości zmniejsza się wraz z czasem przebywania osoby w stanie bezrobocia [Bąk 2015: 52-55]. Dużą uwagę zwraca się również na aspekt dochodowy związany z bezrobociem, brak pracy przekłada się na brak środków niezbędnych do życia, co wpływa na brak możliwości zaspokojenia wszystkich podstawowych potrzeb człowieka. Wówczas przestępstwo może być motywowane chęcią jego osiągnięcia [Sztaudynger i Sztaudynger 2004, dostęp 29.02.2019]. Wpływa to także na wzrost dysproporcji płacowych w regionie, wówczas czyn przestępczy może być motywowany chęcią ich wyrównania. Należy jednak zaznaczyć, że nie każdy rodzaj bezrobocia ma kryminogenny charakter, dotyczy to zwłaszcza kobiet, które często nie podejmują pracy z uwagi na podjęcie obowiązków domowych związanych np. z wychowaniem dzieci [Kądziołka 2014:15-17].

Przeprowadzone badania naukowe wskazują także na zależność pomiędzy wykształceniem, wiekiem oraz płcią osób dokonujących przestępstwa. Analizy takie są jednak dokonywane najczęściej w ramach poszczególnych rodzajów przestępstw, nie w wymiarze zagregowanym. W przypadku przestępstw dotyczących „prania pieniędzy” lub też wyłudzeń kredytowych, osoby biorące udział w oszustwie najczęściej legitymują się niskim wykształceniem i są one bardzo często wykorzystywane jako tzw. „słupy”, pozwalające na uniknięcie kary przez prawdziwego sprawcę czynu zabronionego. Przestępstwa na mieniu natomiast bardzo 
często dokonują osoby młode. $\mathrm{W}$ dalszym ciągu statystyki wskazują również na mniejszą skłonność kobiet do popełnienia czynu przestępczego [Kądziołka 2015: 83-85].

Dodatkowo często uwzględnianymi czynnikami ekonomicznymi są warunki życia ludności oraz tempo wzrostu gospodarczego. Prezentują one przewidywany poziom życia społeczeństwa. Spodziewamy się, że im lepsze warunki życiowe oraz szybsze tempo wzrostu gospodarczego, tym niższy powinien być wskaźnik przestępczości w regionie. Ważnym wskaźnikiem w tym obszarze jest tzw. poziom ubóstwa społecznego, który przedstawia liczbę osób żyjącą poniżej minimum egzystencjalnego (dotyczy osób, których zasoby finansowe nie pozwalają w pełni zaspokoić podstawowych potrzeb egzystencjalnych). Im większy stopień ubóstwa na danym obszarze, tym spodziewamy się większej liczby potencjalnych przestępstw [Sztaudynger 2007: 133-164; Sztaudynger i Sztaudynger 2004, dostęp 29.02.2019].

Nie można $w$ ramach analiz przestępczości pominąć również sprawności i skuteczności organów ścigania oraz wymiaru sprawiedliwości. Zgodnie z założeniami, wraz ze wzrostem poziomu wykrywalności przestępstw oraz należną dotkliwością kary wynikającej z czynu zabronionego spada skłonność do jego popełnienia [Sztaudynger i Sztaudynger 2004, dostęp 29.02.2019].

Przedstawione czynniki najczęściej znajdują swoje uzasadnienie w ramach analiz makroekonomicznych. W przypadku analiz mikroekonomicznych nie zawsze wszystkie ze wskazanych czynników znajdują swoje uzasadnienie [Florczak 2013: 14-15]. W celu poprawy jakości wskazanych analiz w skali mikro obserwuje się wykorzystanie wskaźników syntetycznych reprezentujących jakość życia społeczno-ekonomicznego występującego w obszarze badania [Kądziołka 2015]. Ma to swoje uzasadnienie z uwagi na jego kompleksowy charakter, pozwalając tym samym na uwzględnienie kilku płaszczyzn, przez co rozważane obszary charakteryzują się większą różnorodnością.

\section{PRZESTĘPCZOŚĆ W POLSCE}

W 2017 roku odnotowano w Polsce 753963 przypadków przestępstw, co oznacza, że na każde 100 osób przypadają 2 czyny karalne. Analizując liczbę przestępstw w Polsce po roku 1999 możemy dojść do wniosku, że pomimo niewielkich wahan, stopniowo $\mathrm{z}$ biegiem lat ich liczba się zmniejsza, co jest zjawiskiem pozytywnym. $\mathrm{Na}$ rysunku 1 przedstawiono odpowiednio liczbę przestępstw wykrytych oraz stwierdzonych w Polsce w latach 1999-2017. Największą liczbę przestępstw wykrytych odnotowano w 2004, najmniejszą natomiast w 2016 roku. 


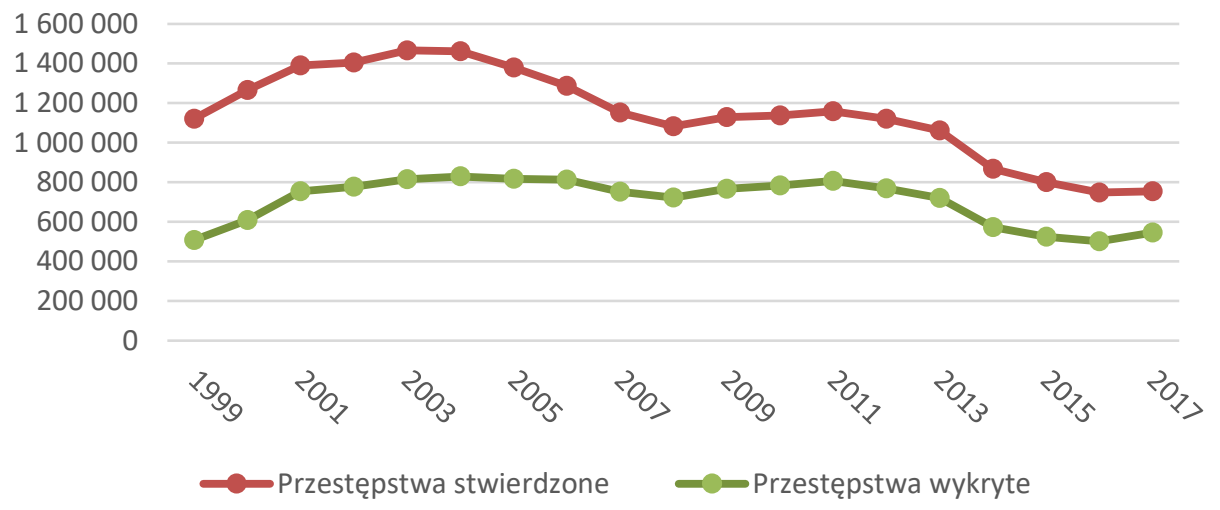

Rysunek 1. Liczba przestępstw stwierdzonych oraz wykrytych w Polsce w latach 2008-2017

Źródło: opracowanie własne na podstawie danych raportu „Przestępstwa stwierdzone ogółem” z zasobów danych Komendy Głównej Policji według stanu na 8.2018.

Na rysunku 2 przedstawiono wskaźnik reprezentujący \% wykrycia przestępstw, który stanowi stosunek pomiędzy liczbą przestępstw stwierdzonych a liczbą przestępstw wykrytych. Pozwala on na prezentację skuteczności policji w zwalczaniu działalności przestępczej. W okresie 1999-2011 prezentacja graficzna obserwowanego zjawiska wskazuje na jego wyraźny trend wzrostowy. W kolejnych latach analizy obserwuje się nieznaczny spadek, jednak już dla kolejnych lat zauważalna jest silna tendencja wzrostowa. Jest to pożądany kierunek zmian badanego zjawiska, ponieważ wskazuje to na wzrost bezpieczeństwa społecznego wynikający z wysokiej skuteczności organów ścigania. Dodatkowo przeprowadzono analizę wielkości zmian wskaźnika dla kolejnych lat analizy, poprzez stworzenie indeksu łańcuchowego, prezentując w ten sposób jego dynamikę. Zgodnie z uzyskanymi wynikami, najwyższy przyrost wartości w stosunku do poprzedniego roku analizy obserwujemy w 2001 roku (12,55\%), najniższy natomiast dla 2014 roku $(-2,69 \%)$. W latach 2007-2014 obserwujemy spadkowy trend dynamiki zmiennej, należy jednak zaznaczyć, że w tym okresie zmienna przyjmuje już wysoki poziom. Wybrane okno czasowe analizy obejmuje lata kryzysu finansowego oraz osłabionego tempa wzrostu koniunktury gospodarczej, które z założenia mogą charakteryzować się wzrostem liczby dokonywanych przestępstw. 


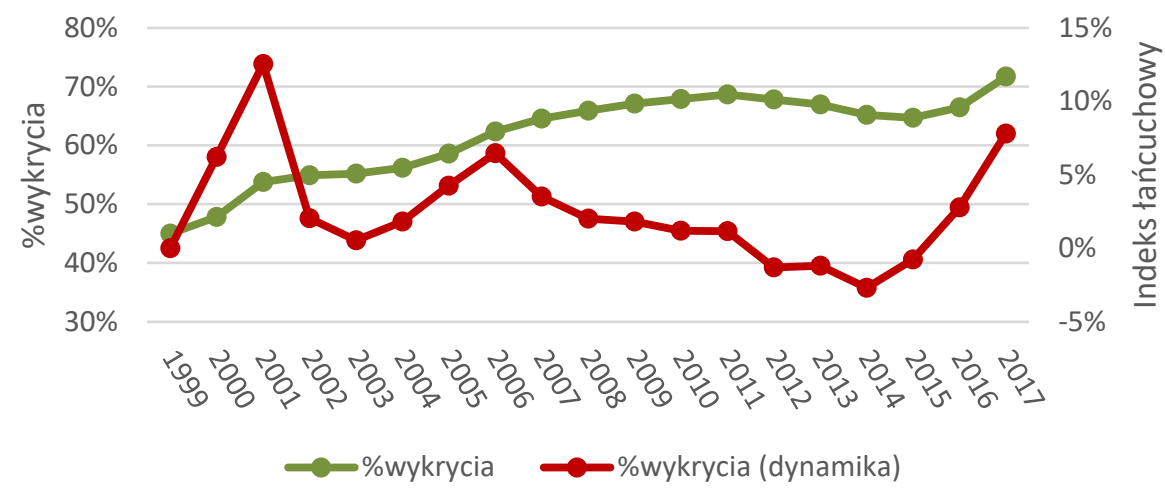

Rysunek 2. Wartość wskaźnika \% wykrycia w latach 1999-2017

Źródło: opracowanie własne na podstawie danych raportu „Przestępstwa stwierdzone ogółem” z zasobów danych Komendy Głównej Policji według stanu na 8.2018.

Powszechnym stwierdzeniem w literaturze tematu jest wyrażenie, że kobiety w mniejszym stopniu skłonne są do dokonywania przestępstw niż mężczyźni. Za główną przyczynę podaje się przede wszystkim czynniki psychologiczne, jak np. w przypadku matek z dziećmi - obawa przed utratą rodziny.

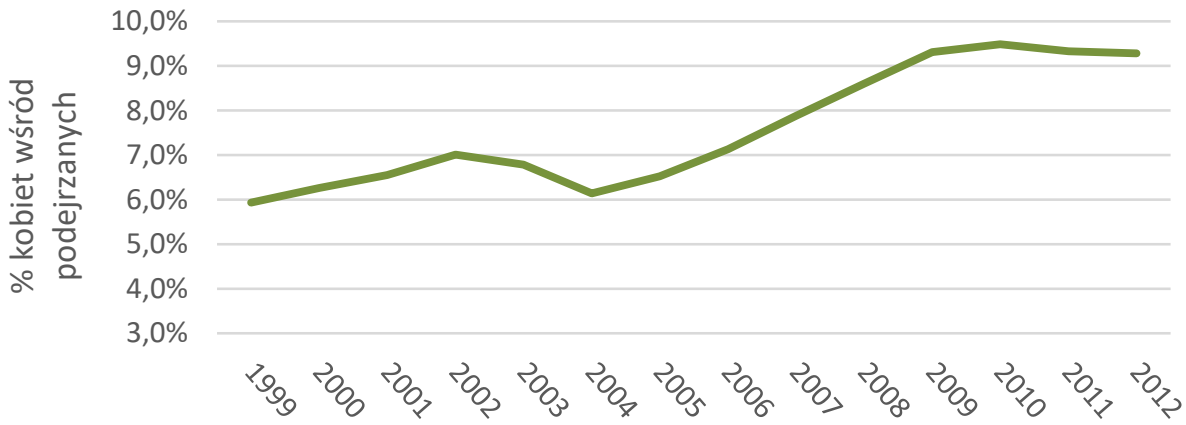

Rysunek 3. Stosunek liczby kobiet podejrzanych o popełnienie przestępstwa do ogólnej liczby popełnionych przestępstw w latach 1999-2012

Źródło: opracowanie własne na podstawie statystyki Policji www.policja.pl.

Na rysunku 3 przedstawiono stosunek liczby kobiet podejrzanych o przestępstwo do ogólnej liczby osób popełnionych przestępstw w danym roku. Możemy zauważyć, że pomimo niewielkich wahań, z biegiem czasu odsetek ten systema- 
tycznie się zwiększa. Najwyższą wartość osiągnął dla roku 2010 i wyniósł 9,5\%, najmniejszą natomiast dla roku 1999 , gdzie kształtował się na poziomie $5,9 \%$. Kobiety w dalszym ciągu stanowią niewielki odsetek osób podejrzanych o popełnienie przestępstwa, co więcej, wskazuje się że najczęściej przestępstwo dokonane przez kobiety ma charakter defensywny, co oznacza, że stanowi odpowiedź na przeprowadzony wcześniej atak [Brzezińska 2017: 18].

Analiza badanego zjawiska na poziomie województw (rysunek 4) wskazuje, że największą liczbą przestępstw stwierdzonych przez policję na 1000 mieszkańców charakteryzują się województwa znajdujące się na zachodzie i południowym zachodzie kraju, w szczególności województwa zachodniopomorskie, lubuskie, dolnośląskie oraz małopolskie. Najniższą wartość analizowana zmienna odnotowała dla województwa podkarpackiego i wyniosła odpowiednio 12.92. Zestawiono te informacje ze wskaźnikiem wykrywalności sprawców (rysunek 5) przestępstw stwierdzonych przez Policję w 2015 roku. Możemy zauważyć, że najwyższą wykrywalność sprawców odnotowuje się w południowo-wschodniej i północno-zachodniej części Polski. Najniższy wskaźnik wykrywalności sprawców obserwowany jest dla województwa mazowieckiego - 53.8\%, najwyższy natomiast dla województwa świętokrzyskiego - 76.4\%.

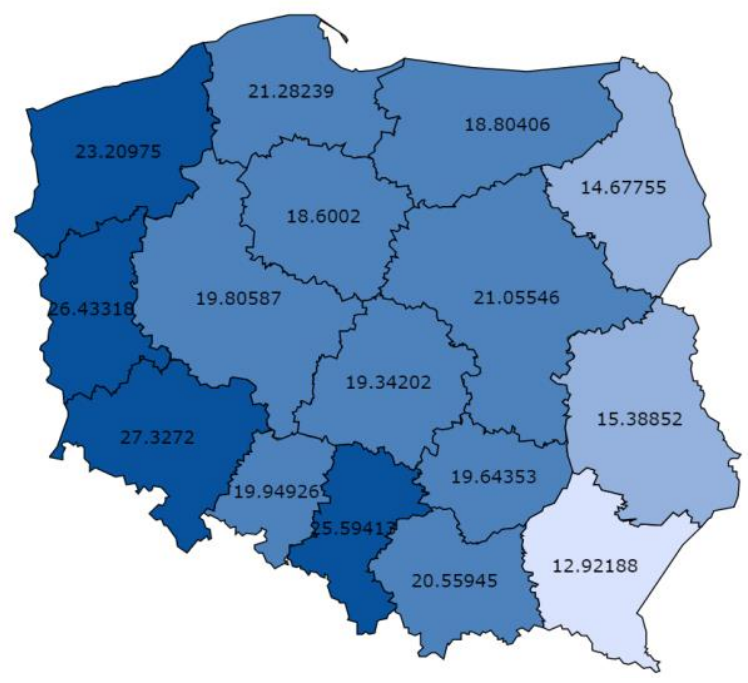

Rysunek 4. Liczba przestępstw stwierdzonych przez Policję na 1000 mieszkańców w roku 2015

Źródło: Portal Geostatyczny, https://geo.stat.gov.pl/imap/ 


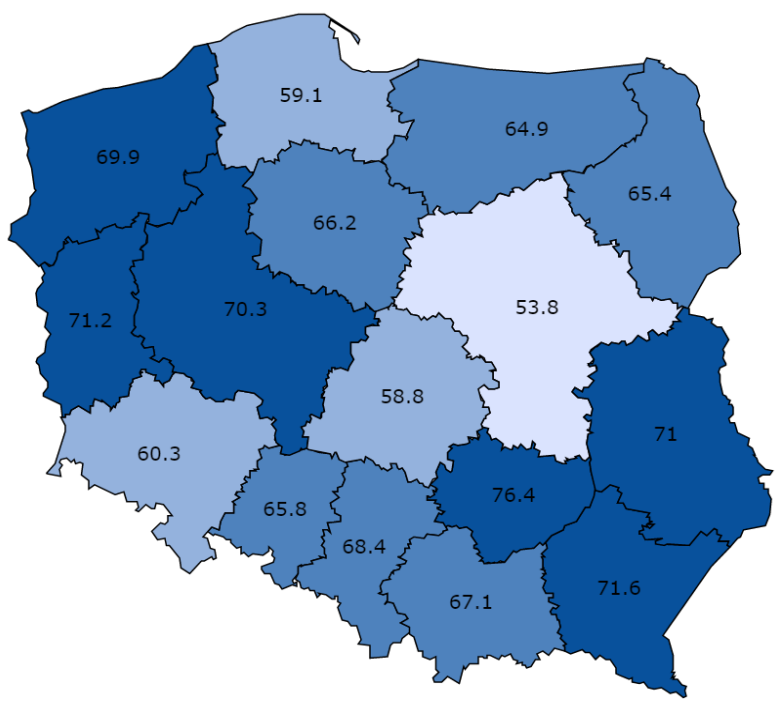

Rysunek 5. Wskaźnik wykrywalności sprawców przestępstw stwierdzonych przez Policję w 2015 roku

Źródło: Portal Geostatyczny, https://geo.stat.gov.pl/imap/

\section{KONSTRUKCJA WSKAŹNIKA JAKOŚCI ŻYCIA}

Rozważania dotyczące badania jakości życia społecznego i ich zasadności wykorzystania w badaniach statystycznych rozpoczęto od interpretacji piramidy potrzeb Maslowa. Uznano wówczas, że człowiek znajduje się w sferze dobrobytu, gdy ma możliwość dążenia do własnej samorealizacji. Z uwagi na czas powstania tej definicji ustalono, że głównym czynnikiem określającym jakość życia jest $\mathrm{PKB}$, ponieważ jednostka posiadająca pieniądze, jest w stanie zakupić wszystko czego potrzebuje do spełnienia celu. Pogląd ten z biegiem czasu z uwagi na wzrost świadomości społecznej uległ znacznym zmianom. Wiązało się to przede wszystkim z obserwacją zmian w środowisku naturalnym oraz dążeniem do nadmiernej efektywności pracy, co nie przekładało się na wzrost satysfakcji społecznej. Postanowiono wówczas odejść od miernika jakości życia opartego wyłącznie o wskaźnik rozwoju gospodarczego jakim jest PKB, na rzecz bardziej złożonych wskaźników [Osika 2018]. Budowa takich wskaźników ma jednak najczęściej charakter arbitralny i zależny od osób przeprowadzających badanie. Najlepiej problem badania jakości życia opisał T. Borys w swojej publikacji, pisząc ,jakości życia nie można uniwersalnie zdefiniować, ponieważ istnieje zbyt wiele sposo- 
bów interpretacji oraz wymiarów, które należałoby uwzględnić, aby możliwe było stworzenie ujednoliconej definicji” [Borys 2002].

Komfort życia społecznego zależny jest od wielu czynników środowiskowych, które obejmują miedzy innymi: stan środowiska naturalnego, bogactwo (w tym: dostęp do edukacji i kultury), zdrowie i bezpieczeństwo oraz poczucie zakorzenienia w lokalnym środowisku [Kusterka-Jefmańska 2010, dostęp 30.06.2019]. Możemy zauważyć, że cześć z nich, jak np. zdrowie czy poczucie zakorzenienia w lokalnym środowisku, są zjawiskami trudnomierzalnymi i mogą być w znacznym stopniu zależne od jednostki badawczej, dlatego w ramach literatury przedmiotu zdecydowano się na rozróżnienie pojęcia jakości życia poprzez ujęcie jej w sposób subiektywnej i obiektywnej oceny. Ocenę uznajemy za subiektywną, jeżeli odnosi się ona do poziomu zadowolenia jednostki poddanej badaniu ze swojej sytuacji życiowej. Obiektywna ocena jakości życia utożsamiana jest natomiast $\mathrm{z}$ warunkami życiowymi. Oznacza to, że z założenia w przypadku poprawy warunków życia w społeczeństwie zakładamy wzrost miary jakości życia [Błoński i in. (red.) 2017: 11-29] $]^{1}$.

W niniejszej pracy z uwagi na wykorzystanie danych panelowych na poziomie województw zdecydowano się na zbudowanie współczynnika jakości życia, weryfikując przy tym istotność statystyczną skonstruowanej zmiennej w modelu ekonometrycznym przestępczości. Zgodnie z przedstawioną wcześniej teorią, konstrukcja takiego typu współczynników charakteryzuje się subiektywnością i pewnego rodzaju arbitralnością z uwagi na charakter doboru zmiennych (zależy od przekonań i wiedzy osoby przeprowadzającej badanie) oraz sposobu ich agregacji (z uwagi na stosowanie średniej ważonej). Brak jest w literaturze przedmiotu publikacji, które zawierałyby kompletny zakres zmiennych mogących odzwierciedlić sytuację społeczno-ekonomiczną społeczeństwa. Brak jest również informacji wskazujących na wyższość znaczenia czynników ekonomicznych czy też środowiskowych na poprawę jakości życia. Dlatego przy budowie współczynnika w niniejszej pracy, w momencie agregacji zmiennych przypisano podczas kalkulacji średniej ważonej równe wagi dla każdej ze zmiennych ${ }^{2}$.

Dane niezbędne do konstrukcji współczynnika zostały pobrane z dostępnych zbiorów Banku Danych Lokalnych Głównego Urzędu Statystycznego. Wybrano szeregi czasowe posiadające pełny zakres danych dla lat 2005-2016 (ograniczenie wynika z dostępności informacji dotyczących zmiennej egzogenicznej w modelu), które w uznaniu badaczy pozwalają na przedstawienie sytuacji społecznoekonomicznej społeczeństwa na obszarze badania. W ten sposób do konstrukcji współczynnika wykorzystano następujące zmienne:

${ }^{1} \mathrm{~W}$ dalszej części pracy przeprowadzone analizy mają charakter oceny obiektywnej z uwagi na badanie aspektów dotyczących warunków życia społeczności.

${ }^{2}$ Autorzy są świadomi dyskusyjności takiego wyboru. Jakikolwiek inny wybór jednakże również można łatwo poddać pod wątpliwość wykorzystując argumenty o arbitralności takiej decyzji. 
- Średnia powierzchnia mieszkania na osobę;

- Wartość dodatków mieszkaniowych na 1 mieszkańca ogółem;

- Wartość nakładów inwestycyjnych na 1 mieszkańca ogółem;

- Średnia wysokość renty/emerytury;

- Przeciętne miesięczne wynagrodzenie brutto;

- Stopa bezrobocia wg BAEL;

- Liczba osób przypadająca na jedno łóżko szpitalne;

- Stosunek powierzchni terenów zielonych do powierzchni ogółem obszaru badania;

- Liczba kilometrów dróg utwardzonych przypadająca na 10 tysięcy mieszkańców;

- Liczba osób lecząca się z zaburzeń psychicznych związanych z uzależnieniem od alkoholu na 10 tysięcy mieszkańców.

Należy zaznaczyć, że wybrane zmienne charakteryzują się występowaniem różnego kierunku wpływu na poziom życia społeczeństwa, a także wyrażone są w różnych jednostkach miary. Nie pozwala to na ich bezpośrednią agregację. Konieczne jest ujednolicenie kierunku wpływu zmiennych oraz odpowiednie ich znormalizowanie. Zdecydowano się na dokonanie transformacji wszystkich zmiennych do postaci stymulanty. W tym celu przekształcono zmienne o charakterze destymulanty: „Liczba osób przypadająca na jedno łóżko szpitalne”, „Stopa bezrobocia wg BAEL” oraz „Liczba osób lecząca się z zaburzeń psychicznych związanych z uzależnieniem od alkoholu" za pomocą poniższego wzoru.

$$
X_{j}=\frac{1}{X_{j}^{D}+c_{j}}
$$

gdzie:

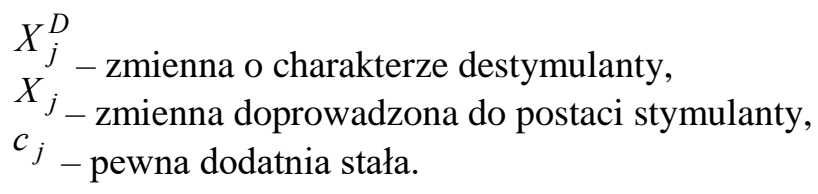

Następnie dokonano normalizacji wszystkich wybranych zmiennych w celu ujednolicenia jednostek, w których są wyrażane. Zastosowana formuła normalizacyjna jest następująca:

$$
Z_{j}=\frac{X_{j}-X_{j}^{\min }}{X_{j}^{\max }-X_{j}^{\min }}
$$


Przyjęcie wskazanej formy normalizacji zapewnia, że nowa wartość zmiennej znajdować się będzie w przedziale wartości $<0 ; 1>$. W kolejnym kroku dokonano sumowania uzyskanych po zastosowaniu normalizacji wartości dla zmiennych przy uwzględnieniu założenia dotyczącego zachowania równych wag oraz sumowania się ich do 1 .

$$
M S_{i}=\sum_{j=1}^{K} w_{j} z_{i j}
$$

Uzyskany w powyższy sposób miernik został zastosowany podczas konstrukcji modelu przestępczości jako jedna ze zmiennych objaśniających.

\section{MODEL DETERMINANT PRZESTĘPCZOŚCI}

Dane wykorzystane w badaniu charakteryzują się częstotliwością roczną i prezentowane są w ramach przekroju ze względu na województwa. Pozyskano je z zasobów Banku Danych Lokalnych Głównego Urzędu Statystycznego. Przedział czasowy analizy obejmuje lata 2005-2016 z uwagi na ograniczenie dostępności części informacji.

Zmienne wykorzystane w modelu:

- Psppn1000 - liczba stwierdzonych przestępstw w zakończonych postępowaniach przygotowawczych na 1000 osób [osoba],

- $\mathbf{x}_{\mathbf{1}}$ - skonstruowany wskaźnik syntetyczny mający na celu prezentację ogólnego poziomu życia społeczno-ekonomicznego w regionie,

- $\mathbf{x}_{\mathbf{2}}$ - współczynnik feminizacji (zmienna w modelu występuje w postaci liczby kobiet na 1 mężczyznę) [osoba],

- $\mathbf{x}_{\mathbf{3}}$ - poziom inflacji [\%],

- $\mathbf{x}_{4}$ - liczba osób mieszkających na terenach miejskich w stosunku całej populacji danego obszaru [\%],

- $\mathbf{x}_{5}$ - liczba osób przypadającą na $1 \mathrm{~km}^{2} \mathrm{w}$ regionie [osoba].

Brak jest nadmiernej korelacji pomiędzy zmiennymi wybranymi do modelu. Najwyższa korelacja obserwowana jest pomiędzy współczynnikiem feminizacji a odsetkiem osób mieszkających na terenach miejskich w stosunku do ogółu ludności $(0,49)$. Zmienna stanowiąca przedmiot badania wykazuje wysoką korelację z odsetkiem osób mieszkających na terenach miejskich $(0,56)$. Tylko dla zmiennej reprezentującej wskaźnik jakości życia możemy zauważyć występowanie ujemnej korelacji ze zmienną reprezentującą przestępczość $(-0,32)$. 
Tabela 1. Macierz korelacji zmiennych

\begin{tabular}{|c|c|c|c|c|c|c|}
\hline $\begin{array}{c}\text { Nazwa } \\
\text { zmiennej }\end{array}$ & L_PSPPN1000 & $\mathbf{x}_{\mathbf{1}}$ & $\mathbf{x}_{\mathbf{5}}$ & $\mathbf{x}_{\mathbf{4}}$ & $\mathbf{x}_{\mathbf{2}}$ & $\mathbf{x}_{\mathbf{3}}$ \\
\hline PSPPN1000 & 1,000 & 0,324 & 0,055 & 0,561 & 0,303 & 0,455 \\
\hline $\mathbf{x} \mathbf{1}$ & $-0,324$ & 1,000 & $-0,018$ & 0,270 & 0,280 & $-0,316$ \\
\hline $\mathbf{x} \mathbf{5}$ & 0,055 & $-0,018$ & 1,000 & $-0,146$ & 0,346 & 0,077 \\
\hline $\mathbf{x} \mathbf{4}$ & 0,561 & 0,270 & $-0,146$ & 1,000 & 0,449 & $-0,003$ \\
\hline $\mathbf{x} \mathbf{2}$ & 0,303 & 0,280 & 0,346 & 0,449 & 1,000 & 0,027 \\
\hline $\mathbf{x}_{3}$ & 0,455 & $-0,316$ & 0,077 & $-0,003$ & 0,027 & 1,000 \\
\hline
\end{tabular}

Źródło: opracowanie własne, wygenerowane przy użyciu programu E-views.

W pierwszym kroku przeprowadzono estymację modelu przy uwzględnieniu występowania w nim efektów FE. Uzyskane w tym etapie wyniki przedstawione w tab. 2, wskazały na brak istotności parametrów stojących przy zmiennych reprezentujących ,liczbę osób na $1 \mathrm{~km}^{2}$ " oraz ,procent ludności mieszkający na terenach miejskich w stosunku do całej populacji regionu".

Tabela 2. Model FE - pierwsza iteracja

\begin{tabular}{|ccccc|}
\hline Variable & Coefficient & Std. Error & t-Statistic & Prob. \\
\hline C & -16.26083 & 2.030986 & -8.006374 & 0.0000 \\
\hline L_x1 & -0.566729 & 0.040059 & -14.14736 & 0.0000 \\
\hline L_x & -10.17431 & 2.478281 & -4.105392 & 0.0001 \\
\hline L_x3 & 4.416109 & 0.383255 & 11.52263 & 0.0000 \\
\hline L_x4 & 0.913714 & 0.856424 & 1.066894 & 0.2875 \\
\hline L_x5 & -0.045406 & 0.243176 & 0.186721 & 0.8521 \\
\hline \multicolumn{5}{c|}{ Effects Specification } \\
\hline R-squared & Cross-section fixed (dummy variables) & \\
\hline Adjusted R-squared & 0.929749 & Mean dependent var & 3.281680 \\
\hline S.E. of regression & 0.921533 & S.D. dependent var & 0.274721 \\
\hline Sum squared resid & 0.076955 & Akaike info criterion & -2.188275 \\
\hline Log likelihood & 1.012673 & Schwarz criterion & -1.831986 \\
\hline F-statistic & 231.0744 & Hannan-Quinn criter. & -2.043975 \\
\hline Prob(F-statistic) & 113.1565 & Durbin-Watson stat & 1.430116 \\
\hline
\end{tabular}

Źródło: opracowanie własne za pomocą programu E-views. 
Zdecydowano się na wykluczenie ich $\mathrm{z}$ analizy z uwagi na ich niewielką zmienność w badanym okresie analizy. Przypuszczalnie zmienne te mogą charakteryzować się wyższą istotnością przy zastosowaniu podziału ze względu na regiony czy powiaty, gdzie różnice te mogą być znaczące.

Po wykluczeniu zmiennych nie wskazujących na istotność w objaśnieniu badanego zjawiska w pierwszej iteracji, przeprowadzono kolejną estymację modelu. Zgodnie z przedstawionymi wynikami w tab. 3, wszystkie pozostawione zmienne w modelu istotnie wpływają na oszacowanie zmiennej endogenicznej, a uzyskane oszacowania są zgodne z zakładaną logiką. Uzyskany model charakteryzuje się nieznacznym spadkiem kryterium informacyjnego względem modelu uzyskanego w pierwszej iteracji, przy równoczesnym zachowaniu niezmienionego poziomu skorygowanego współczynnika determinacji (92\%). Dodatkowo w modelu możemy zauważyć występowanie autokorelacji składnika losowego (wartość statystyki D-W). Stanowi to dodatkowe uzasadnienie zastosowania dynamicznych modeli panelowych.

Tabela 3. Model FE - druga iteracja

\begin{tabular}{|ccccc|}
\hline Variable & Coefficient & Std. Error & t-Statistic & Prob. \\
\hline C & -17.21196 & 1.531955 & -11.23529 & 0.0000 \\
\hline L_x1 & 0.575173 & 0.026334 & -21.84168 & 0.0000 \\
\hline L_x2 & -9.433470 & 2.359035 & -3.998868 & 0.0001 \\
\hline L_x3 & 4.426859 & 0.334347 & 13.24031 & 0.0000 \\
\hline & Effects Specification & \\
\hline R-squared & 0.929281 & Mean dependent var & 3.281680 \\
\hline Adjusted R-squared & 0.921923 & S.D. dependent var & 0.274721 \\
\hline S.E. of regression & 0.076763 & Akaike info criterion & -2.202473 \\
\hline Sum squared resid & 1.019415 & Schwarz criterion & -1.880117 \\
\hline Log likelihood & 230.4374 & Hannan-Quinn criter. & -2.071916 \\
\hline F-statistic & 126.2952 & Durbin-Watson stat & 1.422835 \\
\hline Prob(F-statistic) & 0.000000 & & \\
\hline
\end{tabular}

Źródło: opracowanie własne za pomocą programu E-views. 
W modelach panelowych zakłada się, że nie tylko uwzględnione w nim zmienne mają wpływ na kształtowanie badanego zjawiska. Mają go także niemierzalne, stałe w czasie i specyficzne dla danego obiektu czynniki zwane efektami grupowymi oraz niemierzalne, stałe względem obiektów specyficzne dla danego okresu czynniki, zwane efektami czasowymi. Występowanie efektów FE weryfikowane jest za pomocą Likelihood Ratio Test, efektów RE za pomocą testu Hausmanna. Uzyskane statystyki testowe (tab. 5-6) wskazują na poprawną jakość modelu z wyłącznym uwzględnieniem w modelu efektów FE.

Tabela 4. Likelihood Ratio Test

\begin{tabular}{|l|l|l|l|}
\hline Effects Test & Statistic & d.f. & Prob. \\
\hline Cross-section F & 90.017019 & $-15,173$ & 0.0000 \\
\hline Cross-section Chi-square & 417.660166 & 15 & 0.0000 \\
\hline
\end{tabular}

Źródło: opracowanie własne za pomocą programu E-views.

Tabela 5. Hausmann Test

\begin{tabular}{|l|l|l|l|}
\hline Test Summary & Chi-Sq. Statistic & Chi-Sq. d.f. & Prob. \\
\hline Cross-section random & 25.432561 & 3 & 0.0000 \\
\hline
\end{tabular}

Źródło: ppracowanie własne za pomocą programu E-views.

W literaturze tematu występuje wiele sposobów estymacji w przypadku dynamicznych modeli panelowych (z uwzględnieniem opóźnionej zmiennej endogenicznej, jako zmiennej objaśnianej). Najbardziej znaną i powszechnie stosowaną metodą jest estymator GMM pierwszych różnic Arellano i Bonda zwany FDGMM. W procesie estymacji zastosowano dla tej metody uogólnioną metodę momentów (GMM). Wykorzystanie różnicowania zmiennych wchodzących do modelu pozwala na wykluczenie występujących w modelu stałych efektów grupowych, których występowanie udowodniono we wcześniejszym etapie badania, poprzez potwierdzenie zasadności uwzględnienia w modelu efektów FE.

W procesie modelowania zgodnie ze specyfiką estymacji przy użyciu metody FDGMM, uwzględniono dodatkowe instrumenty będące w tym przypadku czwartym opóźnieniem odpowiednio zmiennej endogenicznej oraz zmiennej reprezentującej dynamikę cen w gospodarce. Modelowano logarytmy wartości poszczególnych zmiennych, a zatem uzyskane parametry mają interpretację elastyczności. 
Tabela 6. Wynik estymacji Model1 FDGMM

\begin{tabular}{|c|ccccc|}
\hline Variable & Coefficient & Std. Error & t-Statistic & Prob. \\
\hline L_PSPPN1000(-1) & 0.366294 & 0.048434 & 7.562723 & 0.0000 \\
\hline L_x1 & 0.446743 & 0.063550 & -7.029742 & 0.0000 \\
\hline L_x2 & -11.67791 & 1.822245 & -6.408530 & 0.0000 \\
\hline L_x3 & 2.769698 & 0.320347 & 8.645935 & 0.0000 \\
\hline \multicolumn{5}{c}{ Effects Specification } \\
\hline & Cross-section fixed (dummy variables) \\
\hline Mean dependent var & 0.055789 & S.D. dependent var & 0.081529 \\
\hline S.E. of regression & 0.087208 & Sum squared resid & 1.186428 \\
\hline J-statistic & 13.46286 & Instrument rank \\
\hline Prob(J-statistic) & 0.336314 & 16 \\
\hline
\end{tabular}

Źródło: opracowanie własne za pomocą programu E-views.

Zgodnie z wynikami zamieszczonymi w tab. 6:

- Przestępczość opóźniona o jeden okres wykazuje istotne statystyczne znaczenie przy kreowaniu wartości bieżącej tego zjawiska, co również potwierdza zasadność wykorzystania metody i przyjętego założenia. Parametr autoregresyjny dla opóźnienia pierwszego rzędu wynosi 0,37 , jego dodatnia wartość motywowana może być uwzględnieniem w badaniu ogólnego poziomu przestępczości, co oznacza, że zawiera różne kategorie przestępstw, w tym np. drobne kradzieże, które przy niskim koszcie krańcowym wynikającym z działalności przestępczej (prawdopodobny niski wymiar kary względem uzyskanych korzyści), mogą w mniejszym stopniu zniechęcać do rezygnacji z ponownego jego dokonania. Dodatkowo, w literaturze przedmiotu istotnego znaczenia nabiera pojęcie recydywy. Stwierdzono w badaniach naukowych, że osoby popełniające przestępstwo $\mathrm{w}$ większym stopniu są skłonne do jego ponownego popełnienia z uwagi na trudną sytuację ekonomiczną po wykonaniu kary. Istotny jest również aspekt społeczny związany z wykluczeniem [Kądziołka 2014: 15-17].

- Wskaźnik prezentujący poziom życia społeczno-ekonomicznego również wskazuje na istotność statystyczną. Kierunek zależności jest zgodny z założeniami, wraz ze wzrostem komfortu życia społecznego obniża się skłonność do popełnienia czynu zabronionego. Przy zachowaniu zasady ceteris paribus wzrost wartości wskaźnika o 1\% spowoduje spadek przestępczości o $0,45 \%$. 
- Podobnie jak i w przypadku modeli z uwzględnieniem efektu FE parametr stojący przy zmiennej reprezentującej współczynnik feminizacji ma ujemny wpływ na liczbę popełnionych przestępstw, co uzasadnia tezę o niższej skłonności kobiet do popełnienia przestępstw. Zgodnie z uzyskanym oszacowaniem, w przypadku wzrostu wartości zmiennej o 1\% nastąpi spadek przestępczości w analizowanym obszarze o ok. 11,68\%.

- Znak parametru stojącego przy zmiennej reprezentującej dynamikę cen w gospodarce jest zgodny z założeniami. Wzrost inflacji o $1 \%$ spowoduje w tym przypadku wzrost liczby popełnionych przestępstw o ok. $2,77 \%$.

W celu weryfikacji poprawności specyfikacji modelu przeprowadzono test Arellano-Bonda badający występowanie autokorelacji większej niż I rzędu. $\mathrm{W}$ tab. 7 przedstawiono uzyskane $\mathrm{w}$ tym procesie wyniki. Przy założeniu 5\% poziomu istotności dla testu, brak jest podstaw do odrzucenia H0 wskazującej na brak w modelu autokorelacji wyższej niż I rzędu. Wskazuje to na poprawną specyfikację modelu, a estymacja za pomocą metody GMM jest w tym przypadku uzasadniona.

Tabela 7. Test autokorelacji Arellano-Bonda dla Model1

\begin{tabular}{|l|l|l|l|l|}
\hline Test order & m-Statistic & rho & SE(rho) & Prob. \\
\hline AR $(1)$ & -2.452962 & 0.499538 & 0.203647 & 0.0142 \\
\hline AR $(2)$ & 0.065718 & 0.007188 & 0.109380 & 0.9476 \\
\hline
\end{tabular}

Źródło: opracowanie własne za pomocą programu E-views.

\section{PODSUMOWANIE}

Niniejsza praca została stworzona w celu weryfikacji prawdopodobnych determinant przestępczości w Polsce w latach 2005-2016. W początkowym etapie badania przeprowadzono analizy statystyczne dotyczące zjawiska zarówno na poziomie kraju, jak i poszczególnych jego województw. Stwierdzono wówczas występowanie trendu spadkowego przestępczości dla najnowszych lat analizy. Najniższą liczbę przestępstw stwierdzonych odnotowano w 2016 roku. W przekroju według województw najniższą przestępczość zaobserwowano dla województwa podkarpackiego, lubelskiego oraz podlaskiego, najwyższą natomiast dla województw lubuskiego oraz śląskiego. Porównanie struktury dokonywanych przestępstw w latach 2010 oraz 2017 wskazało dla obu okresów na występowanie wysokiego odsetka przestępstw o charakterze kryminalnym, a także przestępstw przeciwko mieniu. Za główną z przyczyn wysokiego udziału tego rodzaju 
przestępstw w ogólnej ich strukturze wskazuje się ich specyfikę, która z uwagi na materialność dokonanych szkód jest w znacznie prostszy sposób możliwa do wykrycia przez organy ścigania. Dla 2017 roku zauważalny jest również istotny wzrost przestępstw o charakterze gospodarczym, czego przyczyną może być występujący powszechnie postęp technologiczny oraz wysoka opłacalność przestępstwa przy stosunkowo niskim wymiarze kary.

Istotne znaczenie dla spadku przestępczości zarówno w ramach badań ekonomicznych, jak i socjologicznych ma wzrost wskaźnika wykrycia przestępstw. Prezentuje on skuteczność działania organów ścigania i stanowi stosunek przestępstw wykrytych do przestępstw stwierdzonych. W modelach przestępczości uwzględniany jest jako element kary mający za zadanie uwzględnić niższą skłonność społeczeństwa do popełnienia przestępstwa w regionach, dla których \% wykrycia przestępstw jest wysoki. W Polsce w latach 1999-2007 obserwuje się systematyczny wzrost wskaźnika wykrycia przestępstw. Od 2008 roku natomiast wskaźnik ten utrzymuje się na wysokim poziomie powyżej 65\%. Przeprowadzone analizy prezentujące dynamikę zjawiska wskazują na jego istotny wzrost dla najnowszych lat analizy (2014-2017).

W niniejszej pracy z uwagi na zastosowane metody ilościowe skupiono się przede wszystkim na aspektach mierzalnych. Podjęto działania mające na celu zbudowanie modelu przestępczości dla województw w Polsce. W procesie estymacji analizowanego zjawiska wykorzystano szeregi czasowe z przyjętym przekrojem danych na poziomie województw. Zastosowanie danych panelowych oraz wykorzystanie jako zmiennej objaśniającej opóźnionej zmiennej endogenicznej w modelu spowodowało konieczność wykorzystania dynamicznych modeli panelowych, konkretnie metody FDGMM, z uwagi na jej właściwości oraz stosunkowo prostą metodę obliczenia. Pozwala ona między innymi poprzez różnicowanie zmiennych na wykluczenie z procesu estymacji stałych efektów grupowych. W toku przeprowadzonego badania potwierdzono słuszność wykorzystania wskazanej metody poprzez uzyskanie istotnego parametru znajdującego się przy zmiennej autoregresyjnej znajdującej się w modelu. Kierunek zależności (dodatnia wartość parametru) jest zgodny z zakładaną logiką badanego zjawiska. Jako zmienną endogeniczną przyjęto ogólny poziom przestępczości w regionie, zgodnie z literaturą część z klasyfikowanych w niej przestępstw może charakteryzować się wyższą skłonnością do jego ponownego wykonania. Należy również zaznaczyć, że przeprowadzony test autokorelacji Arellano-Bonda nie wskazał podstaw do odrzucenia hipotezy zerowej, wskazującej na brak autokorelacji wyższej niż I rzędu, co wskazuje na poprawną specyfikację stworzonego modelu. Konstrukcja modelu implikuje występowanie istotnej zależności pomiędzy obserwowanym obecnie poziomem przestępczości w analizowanym regionie a poziomem przestępczości obserwowanym w poprzednim okresie. 
W modelu uwzględniono wskaźnik syntetyczny reprezentujący jakość życia, który został skonstruowany jako suma ważona dziesięciu wybranych wskaźników uprzednio poddanych standaryzacji. Zmienna wskazuje na istotność statystyczną, a uzyskane oszacowanie jest zgodne z zakładaną logiką.

Nie udało się w ramach niniejszego badania potwierdzić hipotezy zakładającej wpływ gęstości zaludnienia oraz stopnia urbanizacji na zjawisko przestępczości. Należy zaznaczyć jednak, że w ramach analizy na poziomie województwa wskazane zmienne nie charakteryzują się dużą zmiennością. Istnieje więc uzasadnienie do przeprowadzenia weryfikacji zasadności ich wykorzystania na poziomie agregacji obszaru badania niższego niż województwo.

Przeprowadzone analizy potwierdzają jednak teorię, zgodnie z którą kobiety

w mniejszym stopniu skłonne są do popełnienia przestępstwa. Świadczą o tym zarówno przedstawione statystyki, jak i istotność parametru stojącego przy zmiennej reprezentującej współczynnik feminizacji w regionie. Stosunek kobiet podejrzanych o przestępstwo do ogólnej liczby osób podejrzanych w danym roku analizy jest w dalszym ciągu bardzo niski. Należy jednak zaznaczyć, że wskaźnik ten dla najnowszych lat analizy systematycznie wzrasta. W ramach literatury naukowej podkreśla się jednak, że najczęściej przestępstwa popełniane przez kobiety mają charakter defensywny.

\section{BIBLIOGRAFIA}

Bąk I., 2015, Struktura i typologia przestrzenna przestępczości w Polsce, „Ekonometria”, nr 50, s. 43-61.

Becker G.S., 1968, Crime and Punishment: An Economic Approach, „Journal of Political Economy", vol. 76(2), s. 169-217.

Błoński K., Burlita A., Witek J. (red.), 2017, Pomiar jakości życia na poziomie lokalnym (na przykladzie powiatu wateckiego), Wydawnictwo Naukowe US, Szczecin.

Borys T., 2002, Jakość, jakość życia oraz pojęcia i relacje pochodne, [w:] W. Ostasiewicz (red.), Metodologia pomiaru jakości życia, Wyd. Akademii Ekonomicznej, Wrocław, s. 58-63.

Brzezińska J., 2017, Przestępczość kobiet wybrane aspekty, Wolters Kluwer, Warszawa.

Czarnecki B.J., 2011, Przestrzenne aspekty przestępczości: metoda identyfikacji czynników zagrożeń w przestrzeni miejskiej, Oficyna Wydawnicza Politechniki Białostockiej, Białystok.

Florczak W., 2013, Co wywotuje przestępczość i jak ja można ograniczać? Wielowymiarowa analiza makroekonomiczna, Wydawnictwo Uniwersytetu Łódzkiego, Łódź.

Kądziołka K., 2014, Wpływ wybranych czynników o charakterze społeczno-ekonomicznym na przestępczość przeciwko mieniu w Polsce, „Studia Ekonomiczne”, nr 181, s. 11-23.

Kusterka-Jefmańska M., 2010, Wysoka jakość życia jako cel nadrzędny lokalnych strategii zrównoważonego rozwoju, „Zarządzanie Publiczne”, nr 12(4), s. 115-122, www.ejournals.eu > pliki > art. [dostęp 30.06.2019].

Osika G., 2018, Jakość życia jako wskaźnik rozwoju społecznego. Analiza mierników, Wydawnictwo Politechniki Śląskiej w Gliwicach, Gliwice. 
Sztaudynger J.J., Sztaudynger M., 2003, Ekonometryczne modele przestępczości, „Ruch Prawniczy, Ekonomiczny i Socjologiczny", nr 3, s. 127-143, http://uoo.univ.szczecin.pl/ dirram/met_il/15///Sztaudynger.pdf [dostęp 29.02.2019].

Sztaudynger J.J., 2007, Spoteczne problemy wzrostu gospodarczego-analiza ekonometryczna, [w:] B. Klimczak, A. Lewicka-Strzałecka (red.), Etyka i ekonomia, Wydawnictwo Polskiego Towarzystwa Ekonomicznego, Warszawa.

\title{
DYNAMIC PANEL MODELS IN THE ANALYSIS OF CRIME DETERMINANTS IN POLAND IN 2005-2016
}

\begin{abstract}
The purpose of this study is to verify an impact of both economic and social factors affecting crime in Poland. The data used in the study is characterized by an annual frequency and is presented as a breakdown by voivodships. The time interval of the analysis covers the years 2005-2016 due to limited data availability. As part of the analyzes, the significance of following variables is verified: feminization rate, inflation, urbanization rates and population density. In addition, in the study a synthetic indicator representing the quality of life in the region is included. The significance of selected variables is verified by econometric model. Due to the use of panel data and the authors' conviction that there is a relationship between past crime values and their current implementations, it is decided to use dynamic panel models (FDGMM method).
\end{abstract}

Keywords: determinants of crime, model of crime, dynamic panel models. 